\title{
PAST AND PRESENT OF RENAL BIOPSY IN THE MANAGEMENT OF PATIENTS WITH GLOMERULAR DISEASES
}

\author{
Marilena Stoian ${ }^{1} 2$ Ana-Maria Dumitrache ${ }^{1}$, Victor Stoica ${ }^{12}$ \\ ${ }^{1}$ Department of Internal Medicine, "Dr. I.Cantacuzino" Hospital, Bucharest \\ 2"Carol Davila "University of Medicine Bucharest
}

\begin{abstract}
Chronic kidney disease (CKD) is a major health problem affecting 10-16\% of the general adult population in Asia, Europe, Australia, and the United States ${ }^{(1,2,3,4,5,6)}$. Progression to end stage renal disease (ESRD) remains a major clinical problem because the number and the cost: there are currently over a million patients worldwide on dialysis, with the number continuing to increase by $\sim 7 \%$ annually ${ }^{(7)}$ and the cost of dialysis is very expensive, costing $\sim$ US $\$ 80,000$ per patient peryear in the United States ${ }^{(8)}$.

Since 1951 when was the first published report of the use of kidney biopsy in the diagnosis of medical kidney disease ${ }^{(9)}$, renal biopsy is an essential procedure in the diagnosis of renal disease, and it is now hard to imagine that one could practice nephrology without knowing pathology. However, there remain no consensus guidelines available to the global renal community outlining the indications for this important diagnostic and prognostic test. In this review, we shall outline the current and potential future uses of renal biopsy in diagnosis, prognosis, response to treatment, and disease progression in the setting of current day nephrology.
\end{abstract}

Keywords: renal biopsy, glomerular diseases, chronic kidney disease, hematuria, proteinuria.

\section{Rezumat}

Boala renală cronică este o problemă majoră de sănătate care afectează 10-16\% din populația adultă din Asia, Europa, Australia și Statele Unite ${ }^{(1,2,3,4,5,6)}$. Progresia spre boala renală în stadiu terminal rămâne o problemă clinică majoră, din cauza frecvenței și costurilor pe care le implică: la nivel mondial, există în prezent peste un milion de pacienți în dializă, numărul acestora continuând să crească cu $\sim 7 \%$ anual ${ }^{(7)}$, iar costul dializei este foarte ridicat, atingând 80.000 USD pe pacient pe an în Statele Unite ${ }^{(8)}$. 


\section{INTERNAL}

\section{General Reviews}

Începând cu 1951, când a fost publicat primul raport privind utilizarea biopsiei renale în diagnosticul afecțiunilor renale ${ }^{(9)}$, biopsia renală este o procedură esențială și în prezent a devenit greu de imaginat că se poate practica nefrologia fără a cunoaște diagnosticul histopatologic. Cu toate acestea, nu dispunem de ghiduri consensuale care să precizeze indicațiile pentru acest test diagnostic și prognostic important. În lucrarea de față, vom prezenta utilitatea actuală și perspectivele viitoare ale biopsiei renale în ceea ce privește diagnosticul, prognosticul, evaluarea răspunsului la tratament și a evoluției afecțiunilor din sfera nefrologiei.

Cuvinte cheie: biopsie renală, boli glomerulare, boli renale cronice, hematurie, proteinurie.

\section{Background}

The introduction of percutaneous renal biopsy in clinical practice has led an important step to a new era of pathology and pathogenesis of glomerular diseases. The diagnosis of glomerular disease in renal biopsy specimens often has at least 5 steps that may occur in different sequences:

1) preliminary review of available clinical data prior to specimen examination,

2) light microscopic examination,

3) immunohistologic examination,

4) electron microscopic examination, and

5) integration of all pathologic and clinical data into a final interpretation and diagnosis.

\section{What are the major clinical uses for a renal biopsy?}

Ideally, the informations derived from a renal biopsy must need the clinician to diagnose kidney disease; to assess prognosis; to monitor disease progression; to aid in the selection of a rational approach to therapy; to monitor and assess response to treatment ${ }^{(10)}$.

A renal biopsy should include at least 10 glomeruli $i^{(11)}$, although $>20$ may be needed to diagnose a focal glomerular disease ${ }^{(12)}$. The minimum sample size for diagnosis varies greatly depending on the underlying diagnosis. Membranous glomerulopathy, for example, may be diagnosed with a single 
glomerulus, whereas post transplant diagnoses are most accurate when the cortical sample exceeds 7 glomeruli. The use of a larger biopsy needle results in a larger fragment of tissue being collected. In one study, the use of a 16-guage (G) needle resulted in an average 70 glomeruli per biopsy, whereas the use of a $22-G$ needle gave 12 glomeruli per biopsy ${ }^{(13)}$. Given that each biopsy sample needs to be processed for light and electron microscopy, as well as immunofluorescence, having only 12 glomeruli is not ideal. The use of a smaller gauge needle usually requires more passes to be made, and evidence suggests that $>5$ passes confer an increased rate of complications $^{(14)}$. Furthermore, given that there is no difference in complication rates between 14-G, 16-G, and 18-G needles ${ }^{(15,16)}$, with most discomfort observed with the largest needle, it is reasonable to recommend a $16-G$ needle for renal biopsy in most circumstances.

Several large prospective and retrospective studies provide an estimate of the frequency of complications after percutaneous renal biopsy $^{(17,18,19,20,21,22,23,24)}$ : (1) death: <0.1\%; (2) major bleeding requiring nephrectomy or surgical hemostasis: $0.1 \%$ to $0.5 \%$; (3) arteriovenous fistula requiring invasive intervention: $0.1 \%$ to $0.5 \%$; (4) blood transfusion requirement: $0.3 \%$ to $7.4 \%$; (5) uncomplicated hematoma: 10 to $90 \%$; and (6) transient macroscopic hematuria : $1 \%$ to $10 \%$.An important step before renal biopsy is to search for factors increasing the risk of complications, particularly bleeding. Although there are no definitive ways to predict which patients will experience complications, several predisposing factors to bleeding have been identified, at times inconstantly.

High blood pressure, age, a decreased GFR, obesity, anemia, low platelet count and small center size ( $<30$ biopsies/year) are associated with an increased risk of bleeding ${ }^{(20,24,25,26,27,28)}$. Amyloidosis was reported to be associated with bleeding ${ }^{(25)}$, although such association was not found in large study by Tøndel el $\mathrm{al}^{(24)}$. As discussed below, hemostasis disorders, anticoagulant or antiplatelet therapy, and certain anatomic conditions, may also contraindicate or complicate percutaneous renal biopsy.

A recent systematic review and metaanalysis of hemorrhagic complications after percutaneous native kidney biopsy using ultrasound guidance and automated springloaded biopsy device reviewed 34 publications and concluded that the predictors of erythrocyte transfusion were: the needle gauge (14 vs. 16 or 18), sex (female), serum creatinine ( $\geq 2 \mathrm{mg} / \mathrm{dL}$ ), low hemoglobin prior biopsy ( $\leq 12 \mathrm{~g} / \mathrm{dL}$ ) and acute kidney injury ${ }^{(27)}$.

Well-trained nephrologists can perform renal biopsy as well as radiologists ${ }^{(29,30)}$. Automated biopsy guns have superseded Tru-cut needles and are probably used in most centers $^{(31)}$. Several studies suggested that 14-18G needles are appropriate for percutaneous renal biopsy ${ }^{(18,32)}$. The use of an automated biopsy gun in combination with real-time ultrasound guidance was reported to provide adequate samples in nearly $99 \%$ of cases, with severe hemorrhagic complications occurring in less than $0.1 \%$. This method can be considered the gold standard $^{(18,25)}$. The use of bedside ultrasound to assess the location and depth of the kidneys was reported as a reliable alternative to real-time guidance ${ }^{(30)}$. In some instances, especially in obese patients, it may be necessary to perform renal biopsy under guidance by CT-scan instead of ultrasound. Transjugular renal biopsy has been reported 


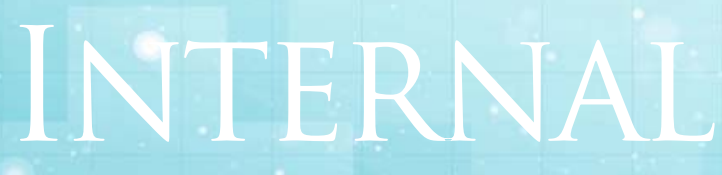

General Reviews

to be a safe and reliable alternative to conventional percutaneous renal biopsy in patients with obesity ${ }^{(33)}$ or those at risk for bleeding, including high-risk patients with coagulopathy and thrombocytopenia ${ }^{(34,35)}$. In these studies, transjugular renal biopsy provided diagnostic yield and safety similar to those of percutaneous approach. However, in most countries, the use of transjugular renal biopsy is limited to a few centers because of the necessity of skilled interventional radiologists.

Laparoscopic renal biopsy has also been reported as an alternative for patients in whom percutaneous approach was not feasible or was contraindicated, because of obesity, solitary kidney, anticoagulation or coagulopathy, or failed percutaneous biopsy. However the number of patients included in these studies was limited and no study has compared the safety of percutaneous, transjugular and laparoscopic renal biopsy in patients at high risk for bleeding. In addition, when considering these procedures, one should carefully contemplate the risk of general anesthesia, perioperative risk and recovery time.

In which clinical settings is a renal biopsy most useful as an aid in the evaluation and management of a patient with undiagnosed kidney disease?
Acute kidney injury (AKI). In the absence of an explanation for AKI when the patient is evaluated initially or when recovery of renal function has not occurred after 3 to 4 weeks of supportive therapy that may include acute dialysis, a kidney biopsy is recommended to distinguish between acute tubular necrosis and those diseases that may require a different therapeutic approach.

Chronic kidney disease (CKD). A renal biopsy may be useful in patients with unexplained CRF and normal-sized kidneys. In contrast, a biopsy is not recommended in the presence of undersized kidneys that have severe parenchymal damage including glomerulosclerosis, chronic vascular injury, and interstitial fibrosis. Kidneys with this degree of disease have a greater propensity for biopsy-induced bleeding.

Nephrotic syndrome. A renal biopsy is generally indicated in infants younger than 1 year of age (possible congenital nephrotic syndrome) and in adults with the nephrotic syndrome and no evidence of systemic disease before therapy is initiated. Children with the nephrotic syndrome are likely to have steroid-responsive disease; thus, biopsy is reserved for those who are unresponsive to a short course of steroids.

Proteinuria. In the presence of persistent proteinuria of $2 \mathrm{~g} / 24$ hours/1.73 m2 or more and especially when associated with an abnormal urine sediment or documented 
functional deterioration, a renal biopsy may be useful to detect an underlying kidney disease. Isolated orthostatic proteinuria is not an indication for biopsy.

Hematuria. Renal biopsy should be reserved for those individuals with microscopic hematuria that has persisted beyond 6 months; in patients with episodic gross hematuria; or in individuals with a family history of hematuria, particularly when associated with proteinuria and/or abnormal urine sediment. Diagnostic possibilities include immunoglobulin $A$ nephropathy, benign essential hematuria, thin basement membrane disease, and Alport syndrome. Renal biopsy is rarely helpful in the clinical setting of short-term, isolated microscopic hematuria. Secondary causes of hematuria such as those resulting from abnormalities in the lower urinary tract must be excluded.

Systemic disease. Disorders such as systemic lupus erythematosus, diabetes mellitus, Schönlein-Henoch purpura, Goodpasture's syndrome, polyarteritis nodosa, various dysproteinemias, and Wegener granulomatosis often manifest kidney involvement. Renal biopsy is frequently useful to establish or confirm a diagnosis and guide subsequent treatment.

Transplant allograft. Renal biopsy is used extensively to differentiate between the various forms of rejection and other causes of kidney failure such as acute tubular necrosis. All these indications are not absolute. In each situation, if associated clinical and laboratory investigation suggest a predictable histological pattern, renal biopsy may not be required. So, the contraindications of kidney biopsy are:

1. absolute: small kidneys; abnormal coagulopathy; uncontrolled hypertension
2. relative: solitary kidney; uncooperative patient; unable to lie flat on bed.

\section{Is a single histological diagnostic enough?}

Ideally, the renal biopsy should identify a specific diagnosis and the severity of the renal disease, can be valuable in improving prognostic accuracy and provide the basis for a decision about specific therapy. Unfortunately, the pathologic diagnosis is often not specific and definitive one; as a result the prognosis and response to therapy cannot always be predicted with confidence ${ }^{(36)}$. Prognostic indicators can be derived from a variety of lesions of renal biopsy: lesions such as glomerulosclerosis, arteriosclerosis, and interstitial fibrosis, if severe and diffuse, indicate a poor prognosis because they are irreversible, slowly progressive, and not responsive to treatment.

(Table 1) On the other hand, intracapillary proliferative and exudative glomerular hypercellularity, even when pronounced, is often completely reversible and does not necessarily indicate a poor prognosis.

(Table 2) Glomerular inflammatory process when associated with necrosis and destruction of basement membranes are more likely to result in glomerular sclerosis. Large crescents (more than $50 \%$ of the glomerular circumference) will instead become fibrotic and destroy the glomerular tuft.

(Table 3) Glomerular capillary thrombi may resolve without residual damage, even without anticoagulant therapy ${ }^{(37,38,39)}$. In the arteries intimal edema and hyaline insudation seem to be potentially reversible, in contrast with an arteritic inflammatory process associated with necrosis who leads 


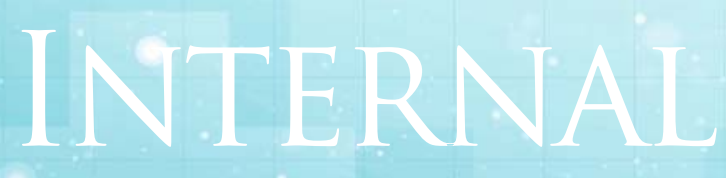

General Reviews

to segmental scarring and destruction of the elastic lamina ${ }^{(38)}$. In general, the presence of severe interstitial fibrosis,tubular atrophy and diffuse glomerular sclerosis indicates irreversible lesions and should discourage an aggressive treatment. Lesions such as increased cellularity, fibrinoid necrosis and cellular crescents are potentially reversible and warrant aggressive treatment.

What is the value of renal biopsy in clinicopathologic correlations in diagnostic and prognostic of glomerular diseases?

A large degree of proteinuria (more than 3 $\mathrm{g} / 24 \mathrm{~h}$ ) is related to lesions in the capillary wall with patent capillary luminal and normal or near-normal glomerular filtration rate. Overall thickening of the glomerular basement membrane (as in membranous nephropathy) or the entire capillary wall (as in mesangiocapillary glomerulonephritis) is invariably associated with proteinuria. Proteinuria may be pronounced in conditions with thin glomerular basement membranes such as minimal change nephropathy or postinfectious glomerulonephritis ${ }^{(38)}$.

Significant hematuria is more likely to correlate with the severity of proliferative and inflammatory lesions than to sclerotic changes in the glomeruli ${ }^{(38)}$.

Severe oliguria or even anuria correlates better with the degree of glomerular and vascular damage, but there is no good correlation between the degree of tubular or interstitial changes and urine output ${ }^{(40)}$.

Interstitial infiltration of leukocytes is common in glomerular diseases; interstitial infiltration of mononuclear cells contributes to the expansion of the interstitial space ${ }^{(41)}$. The interstitial infiltration by mononuclear inflammatory cells but not glomerular infiltration by these cells correlated with decline of renal function $^{(41)}$.

Activated interstitial mononuclear cells are capable of producing secretion of cytokines and growth factors, which are implicated in the pathogenesis of glomerulonephritis. Tubular cells, induce to express HLA-DR antigen ICAM - 1 and C5b-9 and can be a source of vasoactive peptides, growth factors and collagen; all these factors may contribute to the tubulo-interstitial damage and renal fibrogenesis, which is the end-point of tubulo-interstitial inflammation. The intensity of this expression in renal tissue is well correlated with the short and long term outcome of renal function in various forms of human glomerulonephritis.

Measurement of these factors in the urine may be a simple and useful mean for the clinician to follow the activity and the progression of the renal disease or it's therapeutical response. 


\begin{tabular}{ll}
\hline Active lesions & Chronic lesions \\
\hline Proliferation of cells & Glomerulosclerosis \\
Necrosis & Fibrous crescent \\
Cellular crescent & Tubular atrophy \\
Edema & Interstitial tibrosis \\
Active inflammation & Vascular sclerosis \\
Glornerulitis & \\
Interstitial nephritis & \\
Tubulitis & \\
Vasculitis & \\
\hline
\end{tabular}

Table 1. Active and chronic nature of lesion in renal pathology

Epithelial cell

\section{Capsular}

basement membrane

Thickening

changes

$\begin{array}{lll}\text { Proliferation } & \begin{array}{l}\text { Crescentric } \\ \text { nephritis }\end{array} & \text { See details below } \\ \text { Metaplasia } & \begin{array}{l}\text { Diabetes } \\ \text { AKI }\end{array} & \begin{array}{l}\text { Other changes of diabetes } \\ \text { Changes of recovering AKI }\end{array}\end{array}$

Capsular space

Dilatation

Obliteration

\section{Common conditions}

\section{Other associated findings}

Can be as capsular drop Other signs ol renal ischemia Features of chronic tubulointerstitial damage fibrosis Changes of recovering AK

Ischemia to glomerulus Mesangiolysis

Glomerulonephritis

Crescent or necrosis

Proteinous

material in space

AKI: Acute kidney injury

Table 2. Common abnormalities in relation to glomerular capsule 


\section{Conclusions}

Kidney biopsy is an indispensable tool for current practice of evidence-based medicine. The clinicopathologic correlation is a great challenge for both pathologists and nephrologists. Light microscopic examination, immunofluorescence, and electron microscopy should be done routinely in all biopsies. Kidney biopsy, appropriately processed and interpreted, will yield the correct clinicopathologic diagnosis, leading to the appropriate therapeutic strategy while, at the same time, providing key prognostic information.

\section{References}

1. National Kidney Foundation. K/DOQI clinical practice guidelines for chronic kidney disease: evaluation, classification and stratification. AmJ Kidney Dis 2002; 39: 1-266.

2. Chadban SJ, Briganti EM, Kerr PG et al. Prevalence of kidney damage in Australian adults: The AusDiab kidney study. J Am Soc Nephrol 2003; 14: 131-138.

3. Coresh J, Selvin E, Stevens LA et al. Prevalence of chronic kidney disease in the United States. JAMA 2007; 298: 2038-2047.

4. Hallan SI, Coresh J, Astor BC et al. International comparison of the relationship of chronic kidney disease prevalence and ESRD risk. J Am Soc Nephrol 2006; 17: 2275-2284.

5. Wen $C P$, Cheng TY, Tsai MK et al. All-cause mortality attributable to chronic kidney disease: a prospective cohort study based on 462293 adults in Taiwan. Lancet 2008; 371: 2173-2182.

6. Levey AS, de Jong PE, Coresh J et al. The definition, classification, and prognosis of chronic kidney disease: a KDIGO Controversies Conference report. Kidney Int 2011; 80: 17-28.
7. Lysaght MJ. Maintenance dialysis population dynamics: current trends and long-term implications. J Am Soc Nephrol 2002; 13: 37-40.

8. Collins AJ, Foley RN, Herzog C et al. United States Renal Data System, USRDS 2012 Annual Data Report: Atlas of Chronic Kidney Disease and EndStage Renal Disease in the United States. National Institutes of Health, National Institute of Diabetes and Digestive and Kidney Diseases: Bethesda, MD, 2011.

9. Iversen, P. and Brun, C. Aspiration biopsy of the kidney. AmJ Med. 1951; 11: 324-330

10. Madaio MP.Renal biopsy. Kidney Int 1990; 38:529-543.

11. Gerth, J., Busch, M., IIIner, N. et al. Are tissue samples from two different anatomical areas of the kidney necessary for adequate diagnosis?. Clin Nephrol. 2010; 74: 258-265.

12. Whittier, W.L. Complications of the percutaneous kidney biopsy. Adv Chronic Kidney Dis. 2012; 19: 179-187. 13. Roth, R., Parikh, S., Makey, D. et al. When size matters: diagnostic value of kidney biopsy according to the gauge of the biopsy needle. Am J Nephrol. 2013; 37: 249-254

14. Eiro, M., Katoh, T., and Watanabe, T. Risk factors for bleeding complications in percutaneous renal biopsy. Clin Exp Nephrol. 2005; 9: 40-45

15. Manno, C., Strippoli, G.F., Arnesano, L. et al. Predictors of bleeding complications in percutaneous ultrasoundguided renal biopsy. Kidney Int. 2004; 66: 1570-1577

16. Manno, C., Strippoli, G.F., Arnesano, L. et al. Predictors of bleeding complications in percutaneous ultrasoundguided renal biopsy. Kidney Int. 2004; 66: 1570-1577

17. Stratta P, Canavese $C$, Marengo M, Mesiano P, Besso L, Quaglia M, Bergamo D, Monga G, Mazzucco G, Ciccone G. Risk management of renal biopsy: 1387 cases over 30 years in a single centre. Eur J Clin Invest. 2007;37:954-963.

18. Hergesell $O$, Felten $H$, Andrassy $K$, Kühn $K$, Ritz $E$. Safety of ultrasound-guided percutaneous renal biopsyretrospective analysis of 1090 consecutive cases. Nephrol Dial Transplant. 1998;13:975-977.

19. Manno C, Strippoli GF, Arnesano L, Bonifati C, Campobasso N, Gesualdo L, Schena FP. Predictors of bleeding complications in percutaneous ultrasound- 


\begin{tabular}{|c|c|c|}
\hline & Common conditions & Other associated findings \\
\hline \multicolumn{3}{|l|}{ Thick GBM } \\
\hline \multicolumn{3}{|l|}{ Negative IF } \\
\hline & Diabetic nephropathy & EM-Lamina densa thick \\
\hline & & Silver stain no splitting \\
\hline & $\begin{array}{l}\text { Chronic thrombotic } \\
\text { microangiopathy }\end{array}$ & Silver stain splitting of GBM \\
\hline & Hereditary nephritis & Silver stain irregular \\
\hline & & EM basket weaving \\
\hline \multicolumn{3}{|l|}{ Positive IF } \\
\hline & $\begin{array}{l}\text { Membranous } \\
\text { nephropathy }\end{array}$ & Spike by silver stain \\
\hline & & Subepithlial deposits by EM \\
\hline & $\begin{array}{l}\text { Membranoprolilerative } \\
\text { glomerulonephritis }\end{array}$ & Silver stain GBM splitting \\
\hline & & Subendothlial deposits by EM \\
\hline & Amyloid & $\begin{array}{l}\text { Positive light chains } \\
\text { depending on type of } \\
\text { amyloid }\end{array}$ \\
\hline & Fibrillary & $\begin{array}{l}\text { Variable splitting by silver } \\
\text { Fibril by FM }\end{array}$ \\
\hline \multicolumn{3}{|l|}{ Thin GBM } \\
\hline & Alport's syndrome & $\begin{array}{l}\text { Silver stain irregular } \\
\text { EM basket weaving }\end{array}$ \\
\hline & $\begin{array}{l}\text { Benign familial } \\
\text { Hematuria }\end{array}$ & Thin GBM on EM \\
\hline
\end{tabular}

GBM: Glomerular basement membrane, EM: Electron microscopy, IF: Immunoiluorescence

Table 3. Common abnormalities in glomerular basement membrane 


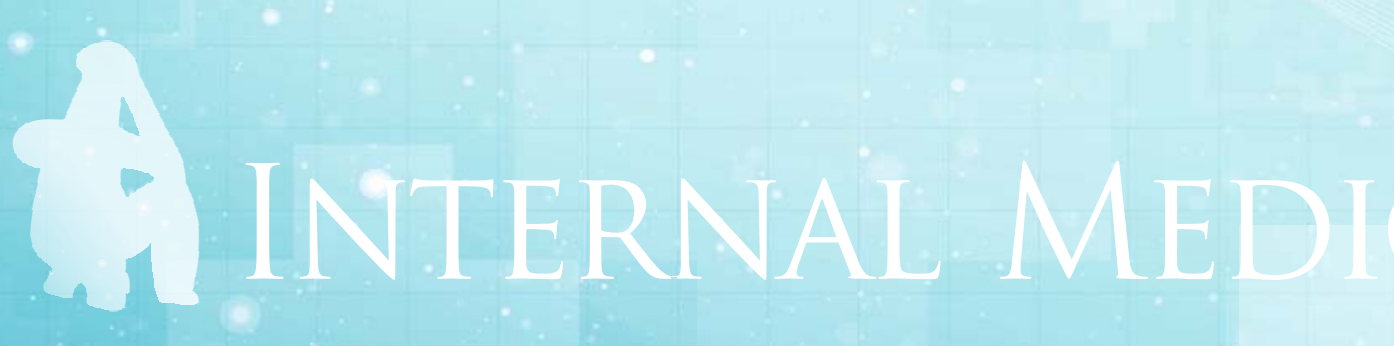

General Reviews

guided renal biopsy. Kidney Int. 2004;66:1570-1577. 20. Mendelssohn DC, Cole EH. Outcomes of percutaneous kidney biopsy, including those of solitary native kidneys. AmJ Kidney Dis. 1995;26:580-585.

21. Burstein DM, Schwartz MM, Korbet SM. Percutaneous renal biopsy with the use of real-time ultrasound. Am J Nephrol. 1991;11:195-200.

22. Ginsburg JC, Fransman SL, Singer MA, Cohanim M, Morrin PA. Use of computerized tomography to evaluate bleeding after renal biopsy. Nephron. 1980;26:240-243.

23. Ralls PW, Barakos JA, Kaptein EM, Friedman PE, Fouladian G, Boswell WD, Halls J, Massry SG. Renal biopsyrelated hemorrhage: frequency and comparison of CT and sonography. J Comput Assist Tomogr. 1987;11:1031-1034. 24. Tøndel C, Vikse BE, Bostad L, Svarstad E. Safety and complications of percutaneous kidney biopsies in 715 children and 8573 adults in Norway 1988-2010. Clin J Am Soc Nephrol. 2012;7:1591-1597.

25. Eiro M, Katoh T, Watanabe T. Risk factors for bleeding complications in percutaneous renal biopsy. Clin Exp Nephrol. 2005;9:40-45.

26. Hedges SJ, Dehoney SB, Hooper JS, Amanzadeh J, Busti AJ. Evidence-based treatment recommendations for uremic bleeding. Nat Clin Pract Nephrol. 2007;3:138-153.

27. Corapi KM, Chen JL, Balk EM, Gordon CE. Bleeding complications of native kidney biopsy: a systematic review and meta-analysis. AmJ Kidney Dis. 2012;60:62-73.

28. Korbet SM, Volpini KC, Whittier WL. Percutaneous renal biopsy of native kidneys: a single-center experience of 1,055 biopsies. Am J Nephrol. 2014;39:153-162.

29. Gupta RK, Balogun RA. Native renal biopsies: complications and glomerular yield between radiologists and nephrologists. J Nephrol. 2005; 18:553-558.

30. Nass K, O'Neill WC. Bedside renal biopsy: ultrasound guidance by the nephrologist. Am J Kidney Dis. 1999;34:955-959.

31. Bollée G, Martinez F, Moulin B, Meulders Q, Rougier JP, Baumelou A, Glotz D, Subra JF, Ulinski T, Vrigneaud L, et al. Renal biopsy practice in France: results of a nationwide study. Nephrol Dial Transplant. 2010;25:3579-3585.
32. Cluzel $P$, Martinez $F$, Bellin MF, Michalik $Y$, Beaufils $H$, Jouanneau C, Lucidarme O, Deray G, Grenier PA. Transjugular versus percutaneous renal biopsy for the diagnosis of parenchymal disease: comparison of sampling effectiveness and complications. Radiology. 2000;215:689-693.

33. Fine DM, Arepally A, Hofmann LV, Mankowitz SG, Atta MG. Diagnostic utility and safety of transjugular kidney biopsy in the obese patient. Nephrol Dial Transplant. 2004;19:1798-1802.

34. Cluzel $P$, Martinez F, Bellin MF, Michalik $Y$, Beaufils $H$, Jouanneau C, Lucidarme O, Deray G, Grenier PA. Transjugular versus percutaneous renal biopsy for the diagnosis of parenchymal disease: comparison of sampling effectiveness and complications. Radiology. 2000; 215:689-693.

35. Misra S, Gyamlani G, Swaminathan S, Buehrig CK, Bjarnason H, McKusick MA, Andrews JC, Johnson CM, Fervenza FC, Leung N. Safety and diagnostic yield of transjugular renal biopsy. J Vasc Interv Radiol. 2008; 19:546-551.

36. Madairo MP.Renal biopsy.Kidney Int 1990; 38;529-543.

37. Danovitch GM, Nissenson AR. The role of renal biopsy in determining therapy and prognosis in renal diasease. Am. J Nephrology 1982; 2:179-184.

38. Pirani CL.Evaluation of kidney biopsy specimens:In : Tisher CC, Brenner BM,eds.Renal Pathology with Clinical and Functional Correlations.Lippincott, Philadelphia, 1994;85-115.

39. Ponticelli C, Mihatsch MJ.Renal biopsy: performance and interpretation.In: Cameron JS, Davison AM, Ritz E , eds.Oxford Texbook of Clinical Nephrology.Oxford Medical Publications, Oxfort.1992;141-155

40. Appel GB, Kunis CL.Acute tubulointerstitial nephritis . In Cottran R, ed. Contemporary Issue in Nephrology, Vol.10, Tubular Interstitial Nephropaties, Churchill, Livingstone, New York, 1983;151-185.

41. Hooke DH, Gee DC,Atkins RC.Leukocyte analysis using monoclonal antibodies in human glomerulonephritis. Kidney Int 1987;32:964-972. 